\title{
A simulation model in evaluating the resilience of urban public transport service during the flood disaster
}

\author{
Yossyafra $^{1, *}$, Ingrid Haryana $\mathrm{B}^{2}$, and Yessi Ferdina ${ }^{1}$ \\ ${ }^{1}$ Civil Engineering Department, Faculty of Engineering, Universitas Andalas, Kampus Limau Manih, Padang,25163, \\ Indonesia \\ ${ }^{2}$ Directorate General of Bina Marga, Ministry of Public Work and Housing, Pattimura Street, Kebayoran Baru, South Jakarta, \\ 12110 , Indonesia.
}

\begin{abstract}
Flood disaster in the urban area can have an impact on the transport of people, goods, and animals. It will certainly result in the disruption of public transportation activities because the road and utilities are probably cannot be passed by vehicles. The objective of the research is to contribute to the analytical basis related to urban public transport services resilience evaluation during the flood. The simulation model is based on the assumption that the primary objective of an urban public transport service during a flood disaster is to continue serving passengers on a predefined service corridor. An example of the application and analysis of this simulation model, simulated for three floods condition, i.e. the first is a high flood prediction that may occur in Padang city (based on The Padang City Development Planning document) and two floods that hit in the year 2016 and 2017. These simulations showed that urban public transport service in Padang city is relatively vulnerable to flood disaster. Lesson learned here have implication for urban public transport services. An interesting outcome of this simulation model has obtained the deviation of urban public transport service route during the flood. There are many parameters that affect the resilience of urban public transport services in the face of floods, and these parameters could be a topic for future research
\end{abstract}

\section{Introduction}

One of the most frequent occurrences of disasters in urban areas is flood inundation, they can have an impact on the movement of people, goods, and animals. Flood disaster with large and high inundation will certainly result in the disruption of public transportation activities because the road infrastructure and utilities are inundated and cannot be passed by people and vehicles.

This article offers a simulation model in analyzing the service resilience of urban public transport systems when the flood occurs in an urban area. The public transport service is simulated by a number of alternate routes of public transport services, the constraint that the alternative route is the closest to the established route. The method in this analysis is mainly simulationoriented, using flood scenarios based on existing flood data and based on official documents of predicted flood maps in a city.

The concept in evaluating of service resilience of urban public transport that is adopted in this research is; how a public transport service can still serve passengers on its service corridor during the flood. When the condition of flood inundation cannot be passed by public transport vehicles, then the vehicle will avoid flood areas by selecting the nearest path that can still be passed around the flood area and back to the existing route (route deviation concept).

\section{Analysis method}

\subsection{Public transport role and route classification}

Public transport plays a very important role in urban development, such as: serving the need for community mobility; the ability to transport large numbers of passengers, which will increase the efficiency of road use; use of public transport can save energy usage; support the socio-cultural interaction of the community. The government must be convinced that public transport service remains in operation when the disaster occurs.

The route is the passage of public passenger vehicles in providing transportation services for people using vehicles, having a fixed origin and destination, fixed track, and scheduled or unscheduled. Meanwhile, the route path is a network of roads that pass by public transport to reach the point of destination from the point of origin. So in a route includes several route paths. Implementation of passenger transportation using public transportation in Indonesia is regulated by legislation. There are four classifications of public transport routes,

* Corresponding author: yossyafra@eng.unand.ac.id 
namely; primary routes, secondary routes, tertiary routes, and direct routes.

\subsection{Route deviation}

Deviations on public transport routes are possible from public transport vehicles (eg bus, midibus) to take roads that are not official routes. This can be caused by certain reasons, such as traffic congestion, road closures due to damage, repair, riot or disaster. When one route path is flooded it will affect the public transport service on the route path. The public vehicles cannot pass the road on the existing routes. Route deviation is to stray from an established/ existing route, where the vehicles have some flexibility to change of route path from existing route. The more deviated public transport from the existing route, then the route deviation rate is higher. Fig. 1 shows how a public transport vehicle deviates into a new route and continues to serve passengers because it is caused by an obstacle from its existing route.

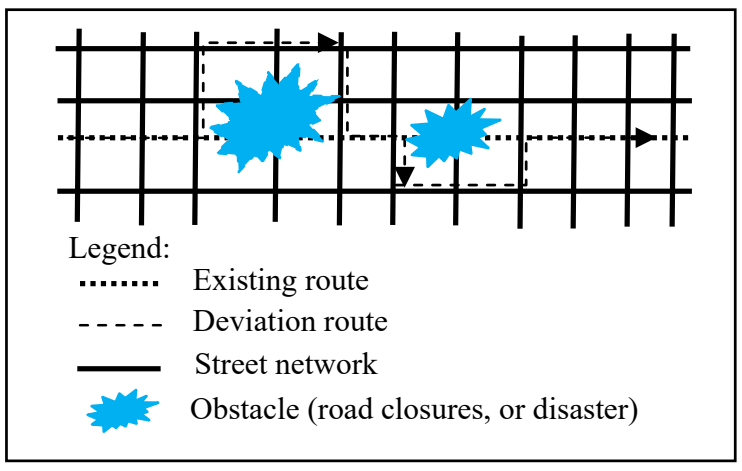

Fig. 1 Deviations on public transport routes

\subsection{Transport resilience indicators and evaluation.}

The term resilience has evolved as different disciplines have applied resilient approaches and adapted the definitions. Levina and Tirpak [1], propose two key differentiates in resilience definitions; being the ability of a system to withstand a disturbance without changing, implying that no damage is done, and the second is the ability of the system to recover when damage has occurred.

Murray-Tuite [2] stated that "resilience is a characteristic that indicates system performance under unusual conditions, recovery speed, and the amount of outside assistance required for restoration to its original functional state". Manyena et.al. [3] also conclude that resilience can be viewed as the "intrinsic capacity of a system, community or society predisposed to a shock or stress to bounce forward and adapt in order to survive by changing its non-essential attributes and rebuilding itself'.

Consider the above conceptions, there are range definitions of resilience:

- the ability of a locale to withstand an extreme natural event without suffering devastating losses, damage, or quality of life and without a large amount of assistance from the outside community [4].

- the capability of a system to maintain its functions and structure in the face of internal and external change...' [5].

- the ability to absorb, adapt to, and/or rapidly recover from a potentially disruptive event [6].

Lee et.al., [7] developed the resilience index in transport systems and has briefly discussed a framework for introducing resilience concepts in transport infrastructure systems. Details for each parameter of transport resilience are still being developed. Victoria Transport Policy Institute [8] has explained that transport resilience can be evaluated at various levels:

- at the individual level, communities have the transportation options needed to meet their transportation needs even in unusual or unexpected circumstances, such as damaged vehicles.

- at the community level, transport systems can safely and efficiently accommodate unusual conditions, including construction projects, hazards, special events and meetings; and the transport system can provide basic accessibility for people with special needs, including people with low incomes or disabilities.

- at the design level, the facility can serve extreme demand and unexpected conditions, including major equipment failures, disasters, and new technologies.

- at the economic level, transportation services can be available if certain resources, such as fuel, become scarce and expensive.

- at the level of strategic planning, transportation systems can meet long-term economic, social and environmental goals under unforeseen circumstances in the future.

\section{Simulation model and case study}

\subsection{Simulation model and analysis steps}

Based on the transport resilience evaluation classification by Victoria Transport Policy Institute [8], the model compiled in this study is a model of the evaluation of resilience transport at the community level. Where in this condition, transport systems can safely and efficiently accommodate unusual conditions including flood disaster.

The following stages are carried out to obtain the objectives of this research, the stages are:

- Collect secondary data: road network map, topographic map, flood inundation map (Fig.2), public transport route (Fig.3),

- Collect primary data: data collection of the depth of flood inundation, when flood disaster occurred and generate a flood inundation map,

- Develop a file by combining several layers of road network maps, flood inundation maps,

- Generate an alternative road layer that can be passed by the vehicle during flood disaster, where the vehicle route is deviated (Fig.4). Route deviation selection considers: (a) the road surface is not inundated, (b) the shortest route, (c) wide road surface $\geq 3.5$ meters. 
- Analyse all the indicators generated (route deviation distance (Fig.5) and time, and area width), from the simulation process of flood inundation on public transport service. Flood inundation area, the length of the route of the public transport route, and the deviation of the public transport route through the flood are obtained (Fig.6). Furthermore, it is analyzed the additional length of the route path and travel time due to route deviation.

\subsection{Case study}

Padang city is on the west coast of Sumatra island, located between $0^{\circ} 44^{\prime} 00^{\prime \prime}$ and $1^{\circ} 08^{\prime} 35^{\prime \prime} \mathrm{SL}$ and between $100^{\circ} 05^{\prime} 05^{\prime \prime}$ and $100^{\circ} 34^{\prime} 09^{\prime \prime E L}$. The air temperature is between $21.6-31.7^{\circ} \mathrm{C}$. Humidity ranges from 78 to 90 percent. The rainfall rate of Padang reaches an average of $302.35 \mathrm{~mm}$ per month with an average rainy day of 17 days per month [9]. Padang is the only city in Indonesia has a river from upstream to downstream. There are 5 major rivers and 16 small rivers flowing from upstream to downstream. Approximately $29 \%$ of the city of Padang is an area with a slope of $0-15 \%$, or with an area of $20.514 \mathrm{Ha}$. And the rest is an area with a slope of more than $15 \%$. It is about $10 \%$ of the Padang area, is an inhabited which is about 900,000 inhabitants (categorized as a big city). In other areas of the city, it is used for agriculture, forestry, plantation, and uncultivated.

Floods disaster, relatively frequent occurrences in Padang, the following factors are believed to be the cause: relatively high rainfall, relatively large amounts of river flows, and poor urban drainage conditions. Hidayat [10], summarized that in the period of the year 20112013 in Padang city, there were 23 times of floods, which can be categorized as flood inundation, flash flood, and rob flood. Flash floods are catastrophic events that bring the greatest loss. Recorded three times Flash Floods disaster, which is on July $24^{\text {th }} 2012$, and September $12^{\text {th }} 2012$, in District Pauh, and October $19^{\text {th }}$ 2013, in District Bungus. The first flood disaster listed above, defined as a provincial-scale catastrophe, has caused a loss of about Rp. 263.9 Billion, in infrastructure, education and housing sector.

A simulation model in evaluating the resilience of urban public transportation is attempted. The flood that will be simulated that impact on public transport service in Padang city are three flood scenarios: the first scenario is High Flood Prediction Scenario (based on Padang City Spatial Plan document 2008-2028), it is called the High Flood Prediction scenario or Flood Hazard Map Scenario. The second is a flood on March $22^{\text {nd }} 2016$, and last is the flood on May $31^{\text {st }} 2017$. Both floods have been raining continuously from night until morning, causing the flood in some areas in Padang, West Sumatra. Based on the observation, at that time the average water level was $50 \mathrm{~cm}$, flooded residents' houses and city streets. It also leads to some streets, private vehicles or public transportation moving to other streets (not the existing route).

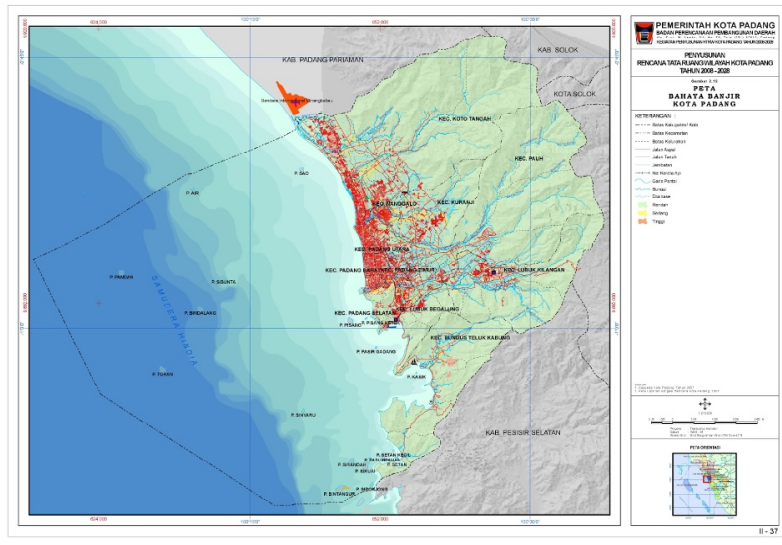

Fig. 2 Flood hazard map of Padang City (Source: Bappeda Padang, 2014)

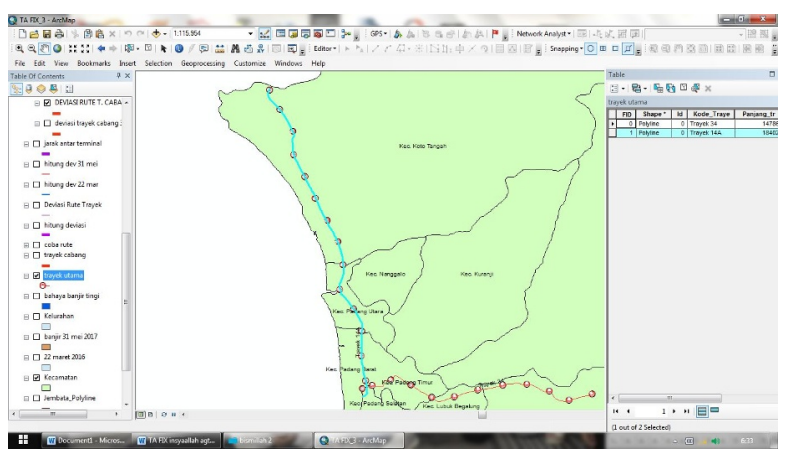

Fig. 3 The primary route network of the public transport route network of Padang city

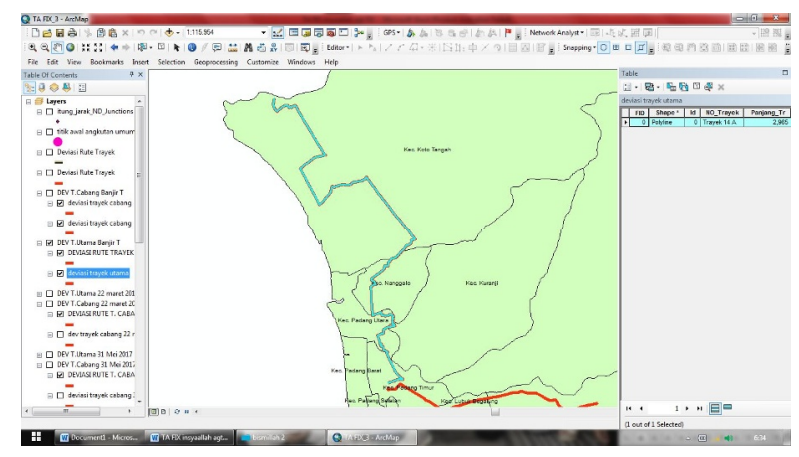

Fig. 4 An example of a route deviation from the primary route network of the public transport route network of Padang city.

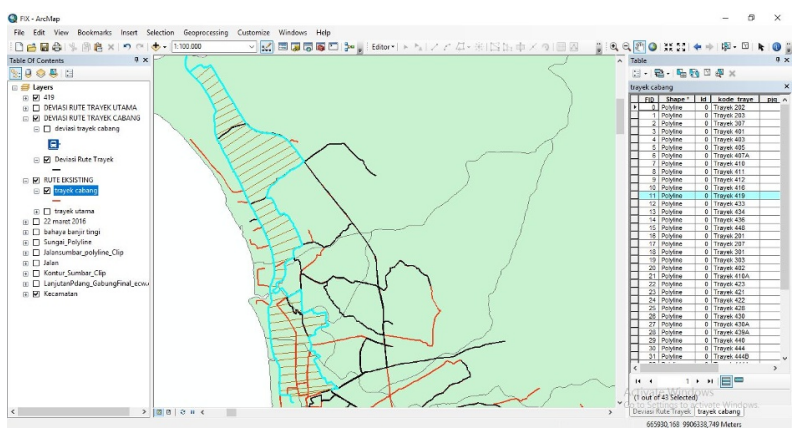

Fig. 5 An example of the distance of a point (Deviation route) to a line (Existing route). 


\section{Analysis and results}

\subsection{Routes affected}

The network of public transportation routes of Padang city is determined by Mayor of Padang, Regulation no. 11 of 2012 on Urban Transport Route Network [11]. Based on the regulation, until the end of 2017, the government has allowed 73 public transport routes, consist of two primary routes, 42 secondary routes, and 29 tertiary routes.

The first step in this simulation model is to combine the layers of each scenario of the flood map on the existing road network or public transport route. From this stage, it is found which routes of public transport are affected by the flood. For the first scenario simulation, it is found that more than 27 public transportation routes in Padang city were affected, resulting in the deviation of the route, with an additional length of the route, and travel time. Based on March 22, 2016 Flood Scenario, only one primary route and 16 secondary routes were not affected, while the other routes effected by increased the length of the route and the travel time. For the third scenario is on May 31, 2017 Flood scenario, it is obtained that all the primary routes and secondary route have deviated.

\subsection{Additional distance and time}

The next step is to calculate the average route deviation that occurs after the impact of a flood by calculating the additional travel distance (Table.1). Based on research Hasmi et.al. [12] that the average speed of vehicles in Padang in passing floods as deep as $10 \mathrm{~cm}$ is with a speed of $14.49 \mathrm{~km} / \mathrm{h}$.

Table 1. Travel distance

\begin{tabular}{|c|c|c|c|c|}
\hline \multirow{3}{*}{$\begin{array}{l}\text { Route } \\
\text { Number }\end{array}$} & \multicolumn{4}{|c|}{ Route Distance $(\mathrm{km})$} \\
\hline & \multirow[b]{2}{*}{ Existing } & \multicolumn{3}{|c|}{$\begin{array}{c}\text { Deviation based on Flood } \\
\text { Simulation Scenario }\end{array}$} \\
\hline & & $\begin{array}{l}\text { High } \\
\text { Flood }\end{array}$ & $\begin{array}{c}\text { On } 22 \\
\text { March } \\
2016\end{array}$ & $\begin{array}{c}\text { On } 31 \\
\text { May } \\
2017\end{array}$ \\
\hline \multicolumn{5}{|c|}{ Primary Route } \\
\hline 34 & 12,67 & 14,79 & 14,79 & 16,83 \\
\hline $14 \mathrm{~A}$ & 18,40 & 29,65 & 20,24 & 19,78 \\
\hline Total & 31.07 & 44.44 & 35.03 & 36.61 \\
\hline \multicolumn{5}{|c|}{ Secondary route } \\
\hline Total & 517,56 & 580,710 & 569,583 & 600,955 \\
\hline
\end{tabular}

Table 2 shows the average percentage of additional travel time from public transport in Padang city, in three simulated scenarios. The speed is also used as a basis for classifying additional travel distance due to flood. Additional travel time or distance, grouped as follows; additional travel time of less than five minutes / additional travel distance of less than $1.2 \mathrm{~km}$, the additional travel time of five to ten minutes / additional distance from 1.2 to $2.4 \mathrm{~km}$, and additional time of more than ten minutes/additions over $2.4 \mathrm{~km}$.

Table 3 shows the number of affected routes (based on distance grouping) for both route types (primary and secondary route). In the simulated model, it is observed that in the high flood prediction scenario, one of the primary routes and seven of the secondary route are affected by route deviation, with an additional distance of more than $2.4 \mathrm{~km}$ or more than an additional 10 minutes.

Table 2. Percentage of travel time additional on each flood scenario

\begin{tabular}{|c|c|c|c|}
\hline \multirow{2}{*}{ Route type } & \multicolumn{3}{|c|}{ Percentage of additional travel time (\%) } \\
\cline { 2 - 4 } & \multicolumn{3}{|c|}{ Flood simulation scenario } \\
\cline { 2 - 4 } & High Flood & $\begin{array}{c}\text { On 22 March } \\
2016\end{array}$ & $\begin{array}{c}\text { On 31 } \\
\text { May 2017 }\end{array}$ \\
\hline Primary Route & 25,58 & 5,54 & 8,40 \\
\hline Secondary route & 13,69 & 13,23 & 14,63 \\
\hline
\end{tabular}

Table 3. Number of routes affected

\begin{tabular}{|c|c|c|c|c|}
\hline \multirow{3}{*}{$\begin{array}{l}\text { Route } \\
\text { type }\end{array}$} & \multirow{3}{*}{$\begin{array}{l}\text { Additional } \\
\text { distance } \\
(\mathrm{km})\end{array}$} & \multicolumn{3}{|c|}{ Number of routes affected } \\
\hline & & \multicolumn{3}{|c|}{ Flood simulation scenario } \\
\hline & & $\begin{array}{l}\text { High } \\
\text { Flood }\end{array}$ & $\begin{array}{c}\text { On 22 } \\
\text { March } \\
2016\end{array}$ & $\begin{array}{c}\text { On } 31 \\
\text { May } \\
2017\end{array}$ \\
\hline \multirow{5}{*}{$\begin{array}{c}\text { Primary } \\
\text { Route }\end{array}$} & Not affected & 1 & 1 & - \\
\hline & $<1.2$ & - & - & 1 \\
\hline & $1.2-2.4$ & - & 1 & 1 \\
\hline & $>2.4$ & 1 & - & - \\
\hline & Total & 2 & 2 & 2 \\
\hline \multirow{5}{*}{$\begin{array}{l}\text { Secondary } \\
\text { route }\end{array}$} & Not affected & 16 & 16 & - \\
\hline & $<1.2$ & 7 & 6 & 19 \\
\hline & $1.2-2.4$ & 12 & 6 & 9 \\
\hline & $>2.4$ & 7 & 14 & 14 \\
\hline & Total & 42 & 42 & 42 \\
\hline
\end{tabular}

The next step is to analyze which routes are vulnerable to flood. Analysis of the vulnerability level of a public transport route to a flood can be done using a Venn diagram (also called a primary diagram, set diagram set or logic diagram). The diagram shows all possible logical relations between a finite collection of different sets. The diagram can also be used as a tool to classify categories of vulnerabilities of public transport routes to flood disasters. It may be categorized as follows: (a) high vulnerable categories, if a public transport route is affected by all flood scenarios; (b) moderately vulnerable categories, if a route is affected by two flood scenarios; and (c) low vulnerable categories if a route is affected by only one of the flood scenarios. Analysis using Venn diagrams can be performed for each route type and each group of additional travel distance. For example, Fig.7 is a vulnerability evaluation performed for the secondary route type and for additional groups of further traveling distance of $2.4 \mathrm{~km}$ due to route deviation due to flood disaster.

Based on a combination of analysis of identification of public transport routes affected by floods (table 3 ) and categorization using Venn diagram analysis (Fig.7). It has concluded that for primary routes; one route is a vulnerable category, and one route is not affected by the three flood scenarios, or it can be categorized as a floodresilient route in the city of Padang. Then for secondary routes: there are six routes with very vulnerable categories, there are seven routes with moderately 
vulnerable categories, two routes can be categorized as low vulnerable categories, and there are about 26 relatively few routes affected by flooding. For these 26 routes, public transport operations are only slightly affected by the added travel time of approximately five minutes or less (or less than $1.2 \mathrm{~km}$ ).

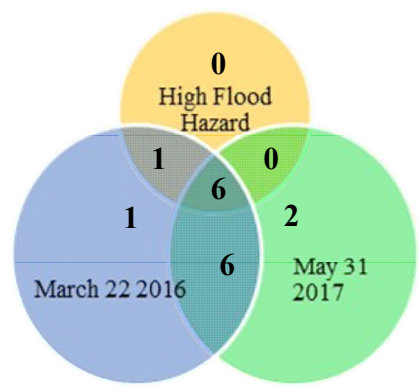

Fig.7 The number of routes affected by the flood scenario

By analysing the existing public transport routes in a city, it can be classified which route should be the attention of the stakeholders in order to remain able to provide public transportation services to the community despite the flood disaster that inundated most of the public transport routes.

\section{Conclusion}

This study has reviewed a concept in evaluating of the resilience of urban public transport service during the flood disaster. The methodology adopted here based on simulation processes. The analysis is based on the assumption that the primary objective of public transport operation is to minimize route deviation during the flood disaster.

From the Padang case study, it can be stated that most public transportation routes in Padang are vulnerable to floods. It has been concluded that one route from the primary route of public transport in Padang is a transport route with a vulnerable category in providing services in case of flooding. Then for the secondary route: there are about six routes with very vulnerable categories, then there are seven routes with moderately vulnerable categories, two routes can be categorized as low vulnerable categories. One primary route and six secondary routes that are the vulnerable category to flood disaster is a route through the North of Padang.

An interesting feature of the results presented in this paper is the ability of this model to evaluate the resilience of urban public transport services during floods. The simulation model built can be used as an initial tool by the city government, to be concerned and willing to consider the flood hazard as part of the public transportation route planning. So that the operational disruption of public transport due to floods can be minimized, to keep providing excellent service to the community at the time of the flood. And this aspect clearly can be a major concern in the resilience of a city's transportation system in the future. This simulation model will be developed continuously by considering the various levels of transport resilience due to various disasters.

\section{References}

1. E. Levina, and D. Tirpak, Adaptation to Climate Change: Key Terms., OECD Env. Directorate (2006)

2. P.M. Murray-Tuite, A Comparison of Transp. Network Resilience Under Simulated System Optimum and User Equilibrium Conditions. Winter Simulation Conf., IEEE, 1398-1405 (2006)

3. S. Manyena, G., O'Brien, P. O'Keefe and J. Rose, Disaster resilience: a bounce back or bounce forward ability? Local Env. 16, (5), 417-424 (2011)

4. D.S., Mileti, Disasters by Design: A Reassessment of Natural Hazards in the U.S. Joseph Henry Press (1999)

5. B. Allenby, and J. Fink, Toward inherently secure and resilient societies. Science 309 (5737): 10341036. (2005)

6. National Infrastructure Advisory Council., Critical Infrastructure Resilience Final Report and Recommendations, US Department of Homeland Security (DHS).

7. Lee, S. J., Kim, J. Y., Lee, S. H., and ChangRichards, Y., (2014), 10th Intern. Conf. of the Intern. Inst. for Infrastructure Resilience and Reconstruction, 20-22 May 2014 Purdue University, West Lafayette, Indiana, USA.

8. Victoria Transport, Policy Institute. Evaluating Transportation Resilience. (2014)

9. Padang's City Development Planning Board, Padang's City Spatial Plan of 2008-2028, Government of Padang City (2012),

10. B., Hidayat, Understanding Flood Disasters in Padang City with Content Analysis News Articles, Pertemuan Ilmiah Tahunan (PIT) HATHI XXXI, Padang, West Sumatra, Indonesia (2014)

11. R Hasmi., Yossyafra., and Nurhamida., Study of Personal Vehicle Speed Link in the city of Padang when the Flood Disaster, Under-graduate Final Project, Universitas Andalas (2016)

12. Mayor of Padang., Regulation no. 11 of 2012 on Urban Transport Route Network, Government of Padang City (2012)

13. K., Heaslip, W., Louisell, and J. Collura, A Methodology to Evaluate Transportation Resiliency for Regional Networks. Transportation Research Board: TRB 88th Annual Meeting Compendium of Papers DVD (2009)

14. P., Tamvakis, and Y., Xenidis, Resilience in Transport Systems, Procedia - Social and Behavioral Sci., 48 pp.3441 - 3450 (2012)

15. A., Cox, F., Prager, and A., Rose, Transport security and the role of resilience: A foundation for operational metrics, Transport Policy, 18, pp.307317 (2011) 
16. J.F., Hughes, and K Healy, Measuring the resilience of transport infrastructure. NZ Transport Agency research report 546. 82pp, ISBN 978-0-478-419153 (electronic) (2014)

17. M., Imran, C., Cheyne, and J., Harold, Measuring Transport Resilience A Manawatu-Wanganui Region Case Study, Massey University Research Online (2014) 